Survey

\title{
Compensation for environmental services from artisanal fisheries in SE Brazil: Policy and technical strategies
}

\author{
Alpina Begossi ${ }^{\text {a,b,* }}$, Peter H. May ${ }^{\text {c,g }}$, Priscila F. Lopes ${ }^{\text {a,d }}$, Luiz E.C. Oliveira ${ }^{\text {a,e }}$, \\ Valéria da Vinha $^{\text {f,g }}$, Renato A.M. Silvano ${ }^{\mathrm{a}, \mathrm{h}}$ \\ a Fisheries and Food Institute(FIFO) and ECOMAR (Graduate Group in Sustainability of Coastal and Marine Ecossystems), Universidade Santa Cecília/UNISANTA, Santos, \\ SP, 11045-040, Brazil \\ ${ }^{b}$ UNICAMP, CAPESCA, PREAC E' CMU, CP 6023, Campinas, SP, Brazil \\ c Graduate Program in Social Sciences in Development, Agriculture and Society, Federal Rural University of Rio de Janeiro (CPDA/UFRRJ), Brazil \\ d Dept. of Botany, Ecology and Zoology, Federal University of Rio Grande do Norte, Natal, Brazil \\ e Natural Resource Institute, University of Manitoba, Winnipeg, Canada \\ ${ }^{\mathrm{f}}$ Institute of Economics, Federal University of Rio de Janeiro, Brazil \\ g National Institute for Science and Technology in Public Policies, Strategies and Development (INCT-PPED), Brazil \\ h Dept. of Ecology, Federal University of Rio Grande do Sul, Porto Alegre, Brazil
}

\section{A R T I C L E I N F O}

\section{Article history:}

Received 21 November 2010

Received in revised form 5 September 2011

Accepted 7 September 2011

Available online 28 September 2011

\section{Keywords:}

Artisanal fisheries

Payments for environmental services

PES

Fishing agreements

FA

Brazil

\begin{abstract}
A B S T R A C T
Artisanal fisheries are of great importance in Brazil, as they are responsible for more than 50\% of national fish production. This importance, associated with the necessity of conserving marine environments threatened by multiple competing uses, leads us to propose mechanisms for co-management of fisheries by users and public authorities. This proposal takes into account: a) local conflicts between artisanal and industrial fishers; b) local rules over the use of fishing areas established by artisanal fishers; $c$ ) the advent of protected areas that close access to some fishing areas used by artisanal fisheries; and d) co-management options being explored between government and fishers. This study suggests policy and technical alternatives under consideration to manage the artisanal fisheries of southeastern Brazil with a focus on Ilha Grande bay in Rio de Janeiro. In our case study, based on field research conducted in 2009, we show that artisanal fishers are squeezed into a marine space between protected areas and industrial fishing. We suggest that a combination of fishing agreements (FAs), based on experience in Amazonian fisheries and extractive reserves, and payment for environmental services (PES), based on forest and related water resource experience, could improve management and livelihoods for local artisanal fisheries by stimulating and rewarding fishers who participate in conservation efforts. The two instruments (FAs and PES) are the subject of considerable research and practical experience. Their integration in an instrument mix represents a contribution from transdisciplinary fields of human ecology and ecological economics.
\end{abstract}

(c) 2011 Elsevier B.V. All rights reserved.

\section{Introduction}

One of the objectives of human ecology is to develop alternatives to management that embody biodiversity demands, human populations' concerns and socio-cultural constraints. Such alternatives can suggest solutions for resource conservation in the productive landscape that do not exclude the humans that depend upon biodiversity for their livelihoods. Marine fisheries represent a particular challenge for resource management, and have been increasingly addressed by both human ecology and ecological economics due to their common property and traditional management characteristics.

\footnotetext{
* Corresponding author at: UNICAMP, CAPESCA, PREAC \& CMU, CP 6023, Campinas, SP, Brazil.

E-mail address: alpinab@uol.com.br (A. Begossi).
}

Small-scale artisanal coastal fisheries are widespread and have great economic and social importance in developing countries, being a reliable and, usually, the primary source of income and animal protein for families of fishers. Despite the generally low intensity of small scale artisanal fishing gear and practices, these fisheries have often not been properly managed. Achieving adequate management is challenging, due to complexity and diversity of tropical artisanal fishing, and to the pressures that come from the conservation of marine biodiversity and from industrial fishing activities in a context of open access. Therefore, it has been argued that new management arrangements, other than the conventional single species and stock management measures adopted in temperate and developed countries, should be undertaken to address these artisanal fisheries (Castilla and Defeo, 2001, 2005; Johannes, 1998; McClanahan et al., 2008; Ruddle and Hickey, 2008). In many countries where artisanal fisheries are managed, the participation of fishers in decision-making processes has led 
to co-management arrangements. Fishers' participation in these arrangements ranges from the inclusion of local rules and norms into management programs to direct participation in legislative processes, as has been observed in Africa, Asia, Oceania, North America, and more recently in South America, including Brazil (Acheson, 2003; Berkes et al., 2006; Hauck and Sowman, 2004; Johannes, 1981, 2002; Pinedo and Soria, 2008; Ruddle, 2000; Seixas et al., 2009).

Due to the incipient nature of local co-management arrangements and a growing concern for marine biodiversity conservation, fishing areas that have long been accessed by artisanal fishers as a traditional right have been increasingly restricted by establishment of marine parks and reserves. As a possible response to this dilemma, we consider below the juxtaposition of co-management instruments such as "fishing agreements" (FAs) and payments for environmental services (PES). This juxtaposition could take the form of compensation for losses associated with resource restrictions with conservation goals (PES), while providing societal benefits through exclusive rights to resource access, in exchange for community management and monitoring of resource stocks (FAs). To encourage co-management of marine artisanal fisheries, Vinha et al. (2010) proposed the use of payments for environmental services in the Arraial do Cabo Marine Extractive Reserve, Rio de Janeiro, as did Begossi et al. (2011) for the management of snappers in Brazil. Such combinations of economic and command and control instruments with resource conservation premises have come to be described as a policy mix (Barton et al., 2010).

In the first section, we describe FAs and PES, their conceptual footing and application to date in the fisheries sector. We then describe the context of artisanal fisheries management in Brazil, and the application of the defeso instrument to compensate fishers for their loss of income during reproductive periods, as well as the creation of protected marine reserves. In the third section, we describe the case study area of Ilha Grande Bay along with relevant results from survey research with fishers there on the tradeoffs they face in observing resource extraction constraints. In the final section, we consider the potential benefits to be obtained from introduction of a policy mix based on the juxtaposition of existing defeso and protected marine areas with fishery co-management and PES. Such measures may offer "winwin-win" outcomes for biodiversity conservation, fishery productivity and social benefits.

\section{Co-Management and Payment for Ecosystem Services in Fisheries}

\subsection{Co-Management and Conservation Externalities}

Co-management can be defined as collaborative and participatory processes of regulatory decision making among stakeholders (Jentoft, 2003), which embody measures for power sharing, capacity building, definition of rights, and linking different systems of knowledge (Berkes, 2007).

In the Brazilian Amazon, innovations in fisheries co-management abound, represented by the creation of extractive reserves and fishing agreements (FAs). Local communities played a major role in the design of these institutional innovations (Begossi et al., 2010). Reserves are protected areas that allow local sustainable activities, but they require some pre-existent local organization in order to be able to respond to stakeholders and carry through on management decisions, not to mention their need to penetrate markets to sustain residents' livelihoods. The creation of a reserve involves high transaction costs (Begossi, 2006), as it has to confront multiple - often conflicting uses of natural resources, as well as to secure the acceptance of stakeholders. Such transaction costs arise from consultations and decision processes embodied in their creation, dynamics and performance (Castro and McGrath, 2001; McGrath et al., 2008).

The creation and achievement of consensus regarding management rules are intrinsic to the creation of co-management schemes. Conflicts may arise if rules are viewed as exogenously imposed. Written statements can be rules-in-form but not rules-in-use (Ostrom, 2005). Those norms imposed by external authorities are often disregarded if pre-existing local rules are not taken into account. External rules tend to "crowd out" endogenous cooperative behavior. This means that in many circumstances when there are local existing rules in the use of a fishing area, such as spatially restricted fishing activities, top-down rules may confuse or enter into conflict with co-management.

One result of the conflict between locally adopted and exogenously applied rules on the use of aquatic spaces is that conservation and subsistence objectives often collide. Resource protectors' argument that preserving coastal areas would assure that fish would survive for their children to catch is not always accepted by fishers, since they have immediate subsistence and market related livelihood necessities. Therefore, a trade-off between current and future livelihoods associated with today's fishing effort is not obvious to fishers. This could indicate a non-convergence between private (fishers) and public (global society) interests in biodiversity conservation (Grafton et al., 2008).

Co-management may help to overcome such non-convergent interests. Kaiser and Edwards-Jones (2006) argue for example that comanagement may be a feasible way to promote eco-labeling in coastal fisheries, because it grants control of fish stocks to local fishers and means to identify origin. Property rights over fishery resources managed by traditional populations can thus permit access to more discriminating markets. Co-management schemes in Brazil such as fishing agreements in Amazonian lakes guarantee access to resources to ensure local livelihoods, combining management mechanisms and integration with the market. Such approaches have also been followed in defining management rights and responsibilities in extractive reserves involving rubber tappers in native forests.

\subsection{Payments for Environmental Services (PES)}

PES represent instruments that may be applicable from a local to global scale to compensate users that agree to refrain either wholly or in part from cultivating extracting or transforming natural ecosystems. PES have been also applied to stimulate users to change their practices of use of natural resources, in order to enhance or maintain the provision of environmental services, such as reforestation of riparian forests to protect water supplies (Wunder et al., 2008).

Some economists have perceived PES primarily as a practical means to internalize environmental costs where command and control instruments have not been altogether successful. Wunder et al. (2008) define PES as a Coasian exchange involving a voluntary transaction of a welldefined environmental service, bought by at least one service buyer from at least one service provider and conditioned on a secure service provision over time through some form of contract. Muradian et al. (2010), on the other hand, describe PES as a means to respond to broader social goals, permitting the establishment of alternative sources for payment (e.g., governmental authorities may make payments from general revenues to fishers who comply with capture restrictions in the public interest rather than expecting individual service "buyers" to make such payments on grounds of self-interest). Furthermore, PES are not necessarily conditional on measurable environmental performance, due to the great degree of uncertainty associated with the links between resource use and environmental benefit and the costs of monitoring and verification. However, it is increasingly true that environmental service "buyers" demand demonstrable results from their investments, rather than taking it for granted that a change in the intensity of resource use will better protect the services that are the object of payment.

Experience in a number of countries has shown that PES schemes may be cost effective (May, 2008) although they may not perform better than other instruments, such as rigid technical restrictions, to achieve reductions in human pressure on natural resources (Ring and Schroter-Schlak, 2011). 
Moreover, PES have not been usually applied so far to marine resources. This may be due to two main reasons. First, PES were developed initially as an instrument suitable for forestry and watershed management and may not have reached marine resource management yet, due to lack of communication between marine and forestry scientists. Second, marine resources, especially fish, show some characteristics that may make the application of PES more challenging: forestry resources (trees) are immobile, visible, have public sympathy (concern over deforestation), and can be more easily monitored (for example, from aerial photographs or satellite images), while marine resources (fish, among others) are for the most part not visible, do not have public sympathy (except for a few, large mammalian species), and are highly mobile, being thus difficult to monitor. An additional challenge resides in the difficulties of assigning defensible resource boundaries in offshore waters: in comparison with forests, fishers are less prone to engage in conservation, as they cannot easily control the actions of other resource users.

Nevertheless, we believe that these caveats can be properly addressed and do not represent insurmountable impediments to application of PES to users of marine resources. Brink (2009) describes examples of public policies to sustain coral reefs, e.g., marine protected areas created to restrict fishing grounds assured greater long term productivity, but short term revenues suffered - compensation to fishers could alleviate these short run costs. Furthermore, undertaking a PES negotiation can potentially achieve different social and ecological outcomes, such as those regarding equity and biodiversity loss. PES can target recipients, in a way that may persuade poor populations to participate in efforts to improve management practices (Pascual et al., 2010).

Strictly speaking, there is already a payment scheme in operation in Brazilian artisanal fisheries, called the defeso. The defeso is a period where fishing activities are forbidden by the government, under which fishers receive a "salary" (based on the minimum wage) to compensate their opportunity costs in deferring fishery activity. The defeso is meant to compensate for fisheries closure during periods of fish reproduction. It began to be employed in 1986, under the responsibility of federal fishery and employment agencies. An associated unemployment insurance program for artisanal fishers has been operational since December 20, 1991 through Law 8.287 (source: Ministry of Labor and Employment, http://portal.mte.gov.br/legislacao/1991-2.htm). The defeso has been applied in Brazil to shrimp, lobster, and in both marine and freshwater fisheries (Freitas et al., 2010; Milani and Fontoura, 2007; Scharer et al., 2011; Souza et al., 2009).

The defeso was initially designed to reduce pressure on stocks, by paying fishermen a compensatory wage during periods of closed fishing seasons, usually between 3 and 4 months of the year. Free riding problems are associated with the defeso mechanism as currently administered (not all beneficiaries depend on fishing for their livelihoods), and it tends to be treated more as a welfare entitlement than a management instrument. There are few surveys evaluating the efficacy of the defeso system, but it is clear that monitoring of outcomes, enforcement and sanctions applied to those who do not comply are rare. Disagreements have arisen over the timing of the closed season and delayed payments in application of the defeso in shrimp fisheries, for example (Lopes, 2008). Evidence exists that the defeso compensation payments can operate as a perverse incentive, motivating excessive resource exploitation by attracting fishers to those species and areas in which the mechanism is operational, thus resulting in fisheries exhaustion rather than protection (Teixeira and Abdallah, 2011). Nevertheless, the defeso system sets a precedent in legislation and practice for compensating marine resource protection by artisanal fishers. A much needed improvement in the defeso could enable it to serve as the basis for more effective PES instruments.

PES schemes are generally often fraught with problems of identifying appropriate service providers, and of monitoring and penalizing where appropriate those who do not actually refrain from resource exploitation. Beneficiary engagement in instrument design and performance monitoring has been cited as critical factor in the success of such schemes (May, 2008).

\section{Artisanal Fisheries in SE Brazil - the Case of Ilha Grande Bay}

Artisanal fish production in Brazil is an activity of great economic and ecological importance, as it corresponds on average to more than $50 \%$ of the total national fish production; for some areas in the north of the country, it reaches 70\% of production (Begossi, 2010; Cordell, 2006; Vasconcellos et al., 2007). However, fisheries management in Brazil has placed a higher priority on inland water bodies than marine resources. Furthermore, in recent years, initiatives by the government to protect coastlines and islands have delimited "no-take" marine reserves, exacerbating conflicts with local artisanal fisheries.

One example in SE Brazil is the Ecological Station of Tamoios (ESEC Tamoios), located in Ilha Grande Bay, including several fishing areas surrounding the historic colonial city of Paraty (Fig. 1). Conflicts over access to waters surrounding islands of the ecological station were observed between the artisanal fishers and the ESEC Tamoios managers who delimit these spaces. Conflicts also occurred between fishers and other stakeholders, such as restaurant owners whose businesses are located on these islands, sport fisherman, divers and industrial trawler fleets (who invade the bay, despite legal restrictions).

Previous studies in Brazil have shown that local rules, such as informal division of fishing spots, can allocate the use of coastal space among local artisanal fishers, thereby decreasing conflicts among them. Such rules, however, do not apply to other users (industrial fishers, for example), who place substantially greater pressures on marine resources but have been less subject to governmental enforcement (Begossi, 2006).The proposed co-management approach espoused here aims to engage stakeholders to address such conflicts, and to assert the resource protective role of traditional fisheries compatible with biodiversity conservation in this complex environment.

\subsection{Ilha Grande Bay Case Study}

Our objective in this study is to assess management prospects for artisanal fishing communities associated with government conservation priorities and protected areas. The SE coast of Brazil is generally characterized by population concentration and corresponding demand for food and income, driven by the tourism industry, limited resource management effectiveness (Begossi, 2010), and probable overfishing.

Protected areas in Brazil are categorized in the National System of Nature Conservation Units (SNUC) according to their permitted uses. In parks, tourism and research are allowed, while in ecological stations, only research is allowed. Resource extraction is prohibited in both these protected area types (Table 1). Coastal conservation units were created to maintain biodiversity and they have been classified into no-take areas and sustainable-use areas (Seixas et al., 2009). Biodiversity conservation in coastal areas of the Atlantic Forest is of recognized global and national importance, and islands can be useful to protect reef fish, constituting areas important for sustaining fishery productivity. The SNUC categories made possible users' participation in management of sustainable-use areas, represented by extractive reserves and sustainable development reserves. However, two important no-take areas located in Paraty Bay (Ecological Station of Tamoios and Bocaina National Park) interfere with artisanal fishers. In this study, we focus on the use of marine space, where the ESEC Tamoios is located.

As is often the case in Brazilian protected areas, the ESEC Tamoios was created through a top-down approach, by a governmental decree that delimits its boundaries, but does not resolve pending resource conflicts. Although nominally under federal management and protection, 


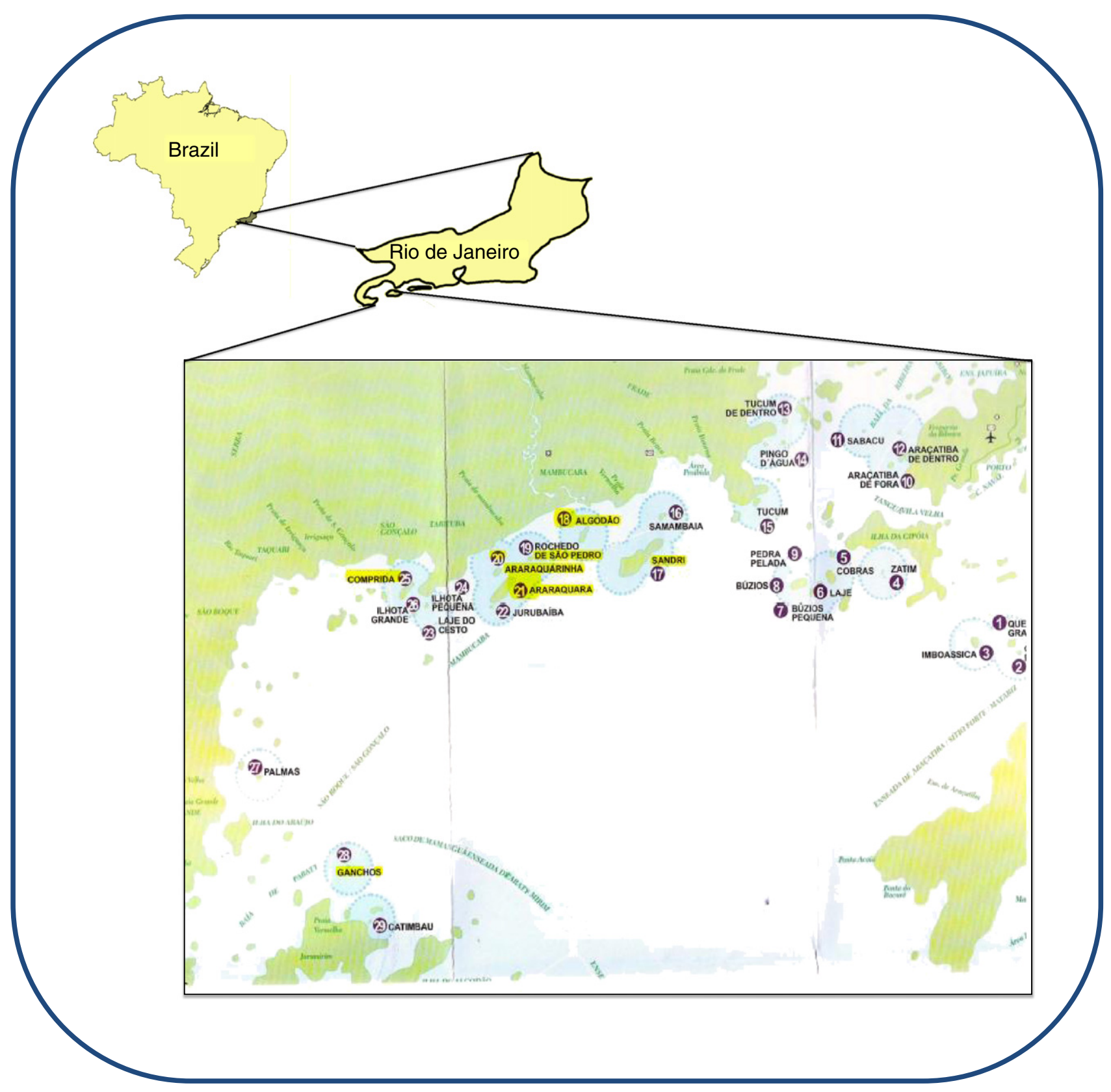

Fig. 1. Location of the study site showing some islands used by local artisanal fisheries located inside the protected area 'Tamoios Ecological Station'.

as most such areas created by governmental fiat, its legitimacy and credibility among artisanal fishers are weak (Begossi, 2010).

The ESEC Tamoios, which includes 29 islands in Ilha Grande Bay and the intervening marine space, was created by Federal Decree 98.864 in 1990 , but its implementation only effectively began in 2008. Our study sites include 34 fishing communities, surrounded by protected areas, including the very restrictive ESEC. The recent fishing prohibition around islands within the ESEC is perceived by local artisanal fishers as a source of conflicts over the use of this marine space (Fig. 2; interviews 2009-2011). Therefore, fishers are currently not prone to comply with restrictions imposed by the ESEC.

Considering these peculiarities, several questions arise for policy and implementation of marine protected areas: What costs will artisanal fishers face by refraining from fishing around restricted islands? To what extent are these fishing restrictions effective in biodiversity protection, and to what extent and over what time horizon could fishers themselves or other stakeholders benefit from the effective protection of these areas from overfishing? Finally, are fishers willing to adhere unilaterally to the ESEC fishing restrictions, considering that resources have not been really protected, because trawlers continue to enter the bay? To answer these questions requires consideration of current property right arrangements and their enforcement in marine fisheries in the area.

\subsection{Conflicts between Fishing Spots and Other Users}

Property rights (formal or informal) in coastal artisanal fisheries in Brazil can be arranged in three systems: 1) the fishing areas locally called pesqueiros by fishers. These areas usually correspond to the ecological definition of 'territories', which are used by specific fishers, based on a set of rules (Begossi, 1995; Nunes et al., 2011). Territoriality was defined in fisheries by McCay and Acheson (1987: 11), as a 
Table 1

Protected areas relevant to this study.

\begin{tabular}{|c|c|c|}
\hline Category ${ }^{a}$ & Objectives & $\begin{array}{l}\text { Example close to } \\
\text { the study sites }{ }^{b}\end{array}$ \\
\hline $\begin{array}{l}\text { Environmental } \\
\text { protection } \\
\text { area }(\mathrm{V})\end{array}$ & $\begin{array}{l}\text { To protect biological diversity and to } \\
\text { regulate occupation aiming to achieve } \\
\text { sustainable uses. Some human occupation } \\
\text { at low density is permitted. Includes } \\
\text { abiotic, biotic and esthetic features } \\
\text { important to the life and well being of } \\
\text { people. }\end{array}$ & APA de Cairuçú \\
\hline $\begin{array}{l}\text { Area of relevant } \\
\text { ecological } \\
\text { interest }(\mathrm{V})\end{array}$ & $\begin{array}{l}\text { To maintain important regional natural } \\
\text { ecosystems. Inhabited areas, including } \\
\text { mosaics of public and private lands, } \\
\text { directed to sustainable development. }\end{array}$ & Ilha Grande ARIE \\
\hline $\begin{array}{l}\text { National or state } \\
\text { park (II) }\end{array}$ & $\begin{array}{l}\text { To protect ecologically relevant and scenic } \\
\text { sites. Environmental education, recreation } \\
\text { and tourism are allowed. }\end{array}$ & $\begin{array}{l}\text { Bocaina National } \\
\text { Park }\end{array}$ \\
\hline $\begin{array}{l}\text { Ecological } \\
\text { station (Ia) }\end{array}$ & $\begin{array}{l}\text { To preserve nature and to undertake } \\
\text { scientific research. Public visitation is not } \\
\text { allowed, except that involving approved } \\
\text { research. }\end{array}$ & $\begin{array}{l}\text { Estação Ecológica } \\
\text { de Tamoios } \\
\text { (ESEC) }\end{array}$ \\
\hline
\end{tabular}

Source: SNUC (National System of Conservation Units) in Law No. 9.985, 2000: http://www.rbma.org.br/anuario/pdf/legislacao_05.pdf.

a The correspondent IUCN (International Union for Conservation of Nature) category of protected area is represented in parenthesis.

$\mathrm{b}$ Located in the municipalities of Angra dos Reis or Paraty.

'redefinition of boundaries of the commons'. According to these authors, 'territoriality can be the basis for the development of rules and regulations about the distribution, use, and transfer of rights in the commons'. These territorial rules can be based on: kinship ties (Begossi, 1995), or on first comer's rules (Seixas and Begossi, 1998), or on mutual consideration or respect (avoidance of fishing in others' fishing spots) (Cordell, 1989; Nunes et al., 2011), among other mechanisms (Begossi, 1995, 2006); 2) the use of fishing areas by different sets of users, such as artisanal fishers with different gear, industrial fishers, divers, recreational fishers and tourists; and 3) governmental rules regarding fishing and the use of the aquatic space. Local rules informally divide use of aquatic space (fishing spots) among local artisanal fisheries, thus avoiding overlap, as has been observed in some artisanal fisheries (Acheson, 2003; Nunes et al., 2011). The fishing spots used in Ilha Grande bay seem to be stable over at least a 20-year period (Begossi, 2006). Nevertheless, government managers rarely recognize such stability and efficacy, and territorial observance does not effectively exclude conflicting users such as trawlers.

\section{Percent of fishers citing major problems in Grande Island Bay (sample $=413$ )}

60

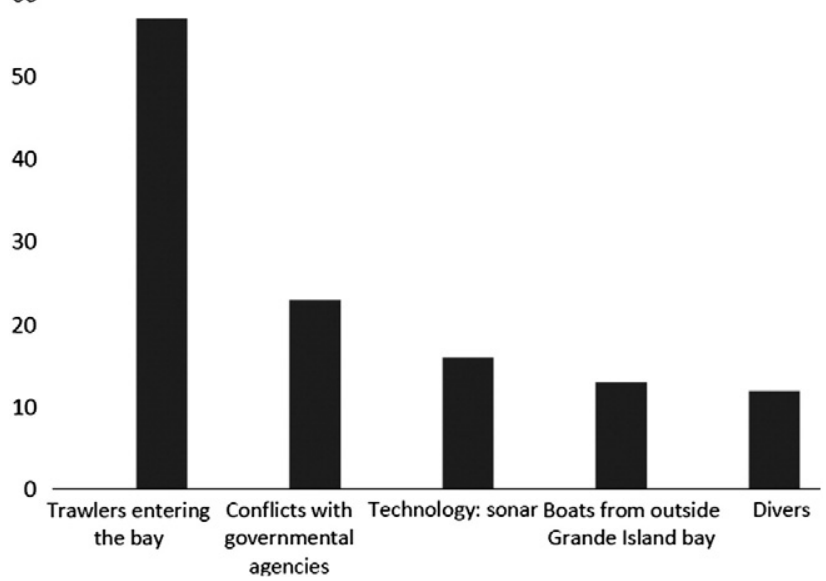

Fig. 2. Percent of fishers (Y axis) citing in interviews the main problems affecting artisanal fisheries of Ilha Grande bay (X axis).
Local resources exploited by the artisanal fisheries in Paraty region include the highly valued shrimp, snooks (Centropomus spp.), and rocky reef species, such as groupers (Epinephelus spp. and Mycteroperca spp.) and snappers (Lutjanus spp.). Artisanal fishing uses mostly set gillnet and hook and line, but other methods, such as diving, are becoming more common.

There is no systematic data collection about Brazilian fisheries resources other than sporadic point estimates of capture rates; therefore, we lack baselines to analyze trends in fish stocks and the relationship between locally available stocks and fishing effort over time. It is however clear that local conflict exists between the industrial and the artisanal fishery, mainly regarding the areas used for fishing. Even if industrial fishers do not target the same species, they usually disrupt the overall coastal ecosystem, reduce fishing productivity and damage fishing gear of artisanal fishers.

In total, 166 fishing spots were cited as used in Paraty, 119 in Angra dos Reis, and 182 in Ilha Grande by artisanal fishing community members interviewed. The most cited fishing spots (considered here as those spots cited by 10 or more fishers in each community) differed by locality, being 19 fishing spots in Paraty (203 fishers), six fishing spots in Angra dos Reis (76 fishers), and 15 in Gipoia and Grande islands (126 fishers) (Begossi et al., 2010). This indicates the local use of the marine area: the interviewed fishers usually concentrated on spots close to their homes. Identification of fishing spots by members of a particular community suggests that they will be more likely to defend their property rights over such spots, which indicates excludability. We follow here the definition by Berkes (1989:6) and by Feeny et al. (1990) on excludability: it is the capacity to exclude outsiders, or, in our study case, other fishers. Management or co-management systems depend upon that capability, among other features.

The problems most cited during interviews with individual fishers are listed in Fig. 2. Fishers expressed most concern with the entrance of industrial fishing trawlers in Ilha Grande Bay. Fishers were also concerned with the presence of the ESEC Tamoios, where fishing is legally forbidden, and with the federal environmental agency, IBAMA, including its surveillance of the islands of the ESEC Tamoios. Local fishers were never consulted about the islands chosen for protection. As a consequence, the ESEC area overlaps with some of the most important fishing spots used by fishers, such as the islands of Araçatiba, Araraquara, Ganchos, Gipóia and Sandri (Fig. 1). Other fishers' concerns were the gear used by industrial boats, such as sonar; the presence of divers (who practice spearfishing), and the lack of enforcement over industrial fishing in the bay. The capture of juvenile fish and baitfish, which could attract large schools of commercially important fish species, is another issue cited by fishers associated with trawler incursions into their fishing spots.

Management suggestions given by fishers to address the cited problems include the proper enforcement of fishing regulations inside the bay, such as forbidding trawling activities and spearfishing."Proper enforcement" as described by fishers implies enforcement without bias or corruption. Fishers (from Grande Island) also suggested as one solution the adoption of fishing agreements (FAs).

Due to an increase in fishing conflicts in the region, the state Secretariat of Fisheries has actively sought to stimulate adoption of fishing agreements that would assure access rights to artisanal fishers, subject to catch constraints. The federal Ministry of Fisheries supports such agreements, but by doing so, enters into conflict with the ecological station, administered by IBAMA, a federal organ subordinated to the Ministry of the Environment, which has insisted on the no-catch policy.

In summary, conflicts identified include the following: 1) artisanal fishers are being squeezed by protected areas and by industrial fishing, recreational fishing (angling and spear) and diving, curtailing traditional fishing rights as perceived by recognized fishing points in the bay islands; and 2) the Ministry of Fisheries supports fishers' claims and has been leading a movement to create fishing agreements, causing conflict with conservation agendas of other government units. 


\section{Co-Managing an Artisanal Fishery through Fishing Agreements (FAs) and Payment for Environmental Services (PES)}

Coastal Brazil exhibits more rigid property right structures over land than over coastal and marine resources, where open access is erroneously assumed to prevail. Coastal communities were occupied initially by indigenous groups whose local exclusive individual property right arrangements coexisted with collective fisheries rules. Although most of these indigenous groups disappeared, surviving traditional communities along the Atlantic coast continue to exhibit some of the original indigenous property rights arrangements. These high-biodiversity environments involve the exploitation of multiple species by multiple gears and fishing techniques, requiring a deep local knowledge of the local marine ecosystem to adjust fishing strategies to each habitat and species (Begossi et al., 2010).

Fishing occurs in an uncertain environment, with fish being an unpredictable resource (Acheson, 1981; McCay, 1981). Such uncertainty is often observed through high variances in fish catches and landings in fisheries. The various forms of dealing with co-management, such as those for governance, social learning, problem solving, and trust building, include forms of building social capital in such unpredictable environments. Flexible, multi-level institutions, along with social networks, are needed and are a form to deal with complexities and uncertainties (Berkes, 2007). Fishing agreements (FAs) are collective agreements with simple mechanisms for managing specific resources. FAs embody few rules between fishers and other stakeholders (which are usually other categories of fishers), are supported legally by a decree, and are administered by the government. Compared to top-down government management regimes, FAs then have the advantage of reduced transaction costs, dealing with specific resource users, such as artisanal fishers, thus involving fewer stakeholders and more specific targets and rules. According to Hanna (2003) there are costs in fishery management that vary with management structure, such as the relative social position of users and government decision-making. The specific involvement of those stakeholders who are directly involved with extraction of marine resources (the artisanal fishers), in the light of their conflicts with other immediate users (industrial fishers, protected areas), makes co-management a local necessity. In this case stakeholders include highly diverse artisanal fishers in Ilha Grande bay that use different technologies and techniques (nets, hook and lines, snook diving-encircling nets, diving, small-trawlers, among others), industrial fishers, owners of industrial boats (armadores), fish buyers, owners of fish markets, restaurant owners, tourist agents, environmental NGOs as well as governmental environmental agencies. Stakeholder roles in management arrangements need to be spelled out and their relative contributions assessed.

\subsection{Combined Co-Management and PES Scheme}

The primary focus of a co-management system for artisanal fisheries is on the fishers themselves and those with whom they come into direct conflict over resource use and access. Such a co-management scheme, incorporating PES in SE Brazil (Ilha Grande and Paraty bays) could be conceived on the following basis:

a) The islands included in the Tamoios Ecological Station (ESEC Tamoios) remain reserved primarily for biodiversity conservation;

b) Artisanal fishers will restrict their own fishing activity around those islands of the ESEC Tamoios and will help in monitoring the islands against trawlers that enter the bay (one aspect of the FA); other activities and uses, such as diving and tourism, may be negotiated with these other stakeholders, being also monitored by local fishers.

c) Artisanal fishing communities jointly or as individuals would receive a payment in the form of a PES for both responsibilities (to avoid fishing in islands and to help in monitoring resource conditions around these islands).
The scheme would involve islands, which have the advantages of being well defined spatial areas that could be monitored through the abundance trends of less mobile reef fish, as well as through selfmonitoring by coastal communities, granted fishing rights over unprotected bay fishing spots. This would help to circumvent a major problem with PES in marine fisheries: lack of spatial boundaries and highly mobile resources. In that regard, the government (the "buyer", interested in resource protection), would pay for services performed by fishers (service providers) in monitoring islands against outside fishers' entrance and for assisting in provision of environmental services (biodiversity conservation). Fishers would be remunerated for monitoring and for their opportunity costs in avoiding to fish around some of the islands, and become co-participants ("co-managers") in the management process in a place where there is a monitoring vacuum. Therefore, fishers could act as sentinels to help government officials in the task of enforcing existing rules.

Funding resources and an appropriate institutional mechanism for payments would have to be developed. The already mentioned defeso, although provided for by law, would need to be adjusted to allow complementary payments of this kind, or its substitution by a more effective PES instrument. Through the PES scheme, other alternative sources of funding could be feasible, such as private companies, as has been observed in Costa Rica (Porras, 2010).

The possibilities of PES were discussed for the first time with fishers in the community of Trindade, near Paraty. Some fishers showed interest in the mechanism, but others showed concern that such a process could exclude them from fishing by stimulating their work as monitors, for example. Therefore, it became clear that fishers have an interest in continuing their artisanal fishing activities, and are wary of schemes that might further constrain their traditional rights. A solution for this shortcoming could be an evolution of the co-management arrangement. If, in the future, fish stocks are recovered, stakeholders could plan for a sustainable use of the islands. FA can be a proper co-management arena where such arrangements can be discussed and implemented.

Fishers may also gain long term benefits from avoiding fishing in no-take zones: first, as shown by several studies worldwide (Gell and Roberts, 2003) and in the Brazilian coast (Francini-Filho and Moura, 2008), fish populations protected inside reserves can increase the fish availability in the fished region outside the reserves through the processes of spillover (movements of adult fish) or recruitment subsidy (transport of eggs and larvae). Therefore, after some time, fishers can experience higher fishing rewards due to the marine reserves. In Chile, after 10 years of co-management through closing areas to fishing, fishing quotas, and other measures, fishers who have been involved with management for a longer time period show more positive environmental perceptions(Gelcich et al., 2008), as these fishers have experienced higher fishing returns and economic rewards as a result of co-management (Castilla and Defeo, 2001; Castilla et al., 2007).

\section{Conclusions}

The research conducted in 2009 with 34 artisanal fishing communities of Ilha Grande bay, SE Brazil (Ilha Grande and Gipóia, Angra dos Reis and Paraty) provides us with knowledge of the use of the marine space by artisanal fishers and of the suggestions fishers give for management of the bay and its resources. In this marine region, conflicts have arisen between artisanal fishers and other stakeholders, such as government environmental agencies, industrial fishers and other claimants to use of protected areas. These conflicts a priori inhibit processes of co-management that could lead to the sustainability of the fisheries.

Artisanal fisheries from Ilha Grande Bay use a high diversity of fishing spots but are concentrated in 40 spots, some located inside an area restricted by ESEC Tamoios. A co-management process involving Fishing Agreements (FAs) and Payment for Environmental 
Services (PES) for Ilha Grande Bay is proposed, including payments to fishers for restricted fishing and for monitoring those islands located within the ESEC. Such new proposed PES can be adapted from the defeso, a quasi-PES scheme already operating in Brazil.

The suggestions for a policy mix (PES combined with FAs) given in this study involve processes with relatively low transaction costs, compared to the other forms of co-management found in Brazil (reserves): they are embedded within the community, with local rules that exist in the use of the marine space, they are flexible, through FAs, which are adaptable as conditions change, and they are realistic, providing rewards and local stimulus for poor artisanal fishers through PES. Furthermore, the approach proposed includes both the carrot of PES and the assurance of ongoing biodiversity conservation through maintenance of the no-catch provisions over selected islands.

In summary, some tools are important in the co-management of artisanal fisheries in SE Brazil, providing mechanisms for their monitoring and maintenance of reserves in islands:

a) More than only hitting fishers with regulatory sticks, carrots through rewards such as PES could provide incentives for fishers to participate in co-management (including monitoring) of the current ecological station, thus creating possibilities of moving them from being opponents to collaborators;

b) Payment could follow the existing legal framework of the defeso system, but would be paid on a year round basis, related to the opportunity costs of permanent fishing restrictions; these opportunity costs may be calculated based on average catch rates in some islands. Even if the regular value paid to fishers is less than the average income from fishing, it would be a secure and predictable source of income, while fishing is uncertain, unpredictable and also incur in costs to fishers. This could make the system cost-effective. Over time, a possible increase in catch rates in fishing spots close to no-take areas could allow for a reduction in compensatory payment to fishers, after proper negotiation.

c) Resources could come partially from the governmental environment agency and partially from local industries in compensation for their environmental impacts, such as TAC - Termos de Ajustes de Conduta [see McGrath et al. (2008)], or from local restaurants that use Paraty Bay for acquiring fish for their touristic markets.

In conclusion, it has become clear through this study that a number of pathways can be explored through transdisciplinary research to develop a unified approach to artisanal fisheries management in SE Brazil. Such a theoretical and practical unification can contribute toward development of appropriate policy formulations that can benefit both those social groups who rely on resource use for their livelihoods and the natural environment itself. Fishing agreements in combination with payments for ecosystem services represent one such pathway to promote resilience among artisanal fisheries in developing countries.

\section{Acknowledgments}

We thank CNPq for permitting this collaborative process with CPDA/UFFRJ, through a Post-Doctoral Senior Fellowship to the principal author (\#151081/2009-2), and to productivity scholarship grants to both herself and Renato A. M. Silvano; Eduardo Camargo for helping in the fieldwork, and Salvador Carpi Jr. for the map. Thanks also to IDRC and FAPESP grants (Nos. 104519-004 and 2009/11154-3, respectively), which allow continuation of the research in the area of Paraty, RJ. Dialog on PES was made possible through participation by Peter May in a European Community FP7 Cooperative Project entitled "Assessing the role of economic instruments in policy mixes for biodiversity conservation and ecosystem services provision," coordinated by the Norwegian Institute for Nature Research (NINA; http:// policymix.nina.no).

\section{References}

Acheson, J.M., 1981. Anthropology of Fishing. Annual Review of Anthropology 10, 275-316.

Acheson, J.M., 2003. Capturing the Commons: Devising Institutions to Manage the Maine Lobster Industry. University of New England.

Barton, D.N., Ring, I., Rusch, G., May, P., DeClerck, F., Vignola, R., Vivan, J.L., Ansink, E., Unnerstall, H., Santos, R., Antunes, P., Browner, R., Grieg-Gran, M., Similä, J., Primmer, E., Romeiro, A., Ibrahim, M., 2010. Assessing the role of economic instruments in a policy mix for biodiversity conservation and ecosystem services provision: a review of some methodological challenges. Policy Mix Discussion Paper 1-2010, $1-29$.

Begossi, A., 1995. Fishing spots and sea tenure: Incipient forms of local management in Atlantic forest coastal communities. Human Ecology 23, 387-406

Begossi, A., 2006. Temporal stability in fishing spots: conservation and co-management in Brazilian Artisanal Coastal Fisheries. Ecology and Society 11, 5 (on-line).

Begossi, A., 2010. Small-scale fisheries in Latin America: management models and challenges. MAST 9, 5-12.

Begossi, A., Lopes, P.F.M., Oliveira, L., Nakano, H., 2010. Ecologia de pescadores artesanais da Ilha Grande. Editora Rima, Sao Carlos.

Begossi, A., Salivonchyk, L.G., Araujo, T.B., Andreoli, M., Clauzet, M., Martinelli, C.M., Ferreira, A.G.L., Oliveira, L.E.C., Silvano, R., 2011. Ethnobiology and snapper conservation in the artisanal fisheries of Brazil: target species and suggestions for management. Journal of Ethnobiology and Ethnomedicine 7, 11.

Berkes, F., 1989. Common Property Resources. Belhaven Press, London.

Berkes, F., 2007. Adaptive co-management and complexity: exploring the many faces of co-management. In: Armitage, D., Berkes, F., Doubleday, N. (Eds.), Adaptive Co-Management. University of British Columbia Press, Vancouver, pp. 19-37.

Berkes, F., Mahon, R., McConney, P., Pollnac, R., Pomeroy, R., 2006. Gestão da pesca de pequena escala: diretrizes e metodos alternativos. Editora Furg, Rio Grande.

Brink, P., 2009. TEEB - The Economics of Ecosystems and Biodiversity in National and International Policy Making. Earthscan, Wesseling.

Castilla, J.C., Defeo, O., 2001. Latin American benthic shellfisheries : emphasis on comanagement and experimental practices. Reviews in Fish Biology and Fisheries $11,1-30$.

Castilla, J.C., Defeo, O., 2005. Paradigm shifts needed for world fisheries. Science 309, 1324-1325.

Castilla, J.C., Gelcich, S., Defeo, O., 2007. Successes, lessons, and projections from experience in marine benthic invertebrate artisanal fisheries in Chile. In: McClanahan, T.R., Castilla, J.C. (Eds.), Fisheries Management Progess Towards Sustainability. Blackwell Publishing Ltd., pp. 25-42.

Castro, F., McGrath, D., 2001. O manejo comunitário de lagos da Amazônia. In: Estratégicos, C.d.E. (Ed.), Parcerias Estratégicas. Ministério de Ciência e Tecnologia, Brasilia, pp. $112-126$.

Cordell, J., 1989. A sea of small boats. Massachusetts, Cambridge.

Cordell, J., 2006. Scaling up marine management: the role of protected areas.

Feeny, D., Berkes, F., McCay, B.J., Acheson, J.M., 1990. The tragedy of the commons: twenty-two years later. Human Ecology 18, 1-9.

Francini-Filho, R.B., Moura, R.L., 2008. Evidence for spillover of reef fishes from a notake marine reserve: an evaluation using the before-after control-impact (BACI) approach. Fisheries Research 93, 346-356.

Freitas, R.R., Reis, V.L., Apel, M., 2010. Governança de recursos pesqueiros na Bacia do Rio Acre com ênfase na Tríplice Fronteira (Brasil, Peru e Bolívia). ANPPAS, Florianopolis, Brazil.

Gelcich, S., Kaiser, M.J., Castilla, J.C., Edwards-Jones, G., 2008. Engagement in comanagement of marine benthic resources influences environmental perceptions of artisanal fishers. Environmental Conservation 35, 36-45.

Gell, F., Roberts, C.M., 2003. Benefits beyond boundaries: the fishery effects of marine reserves. Trends in Ecology \& Evolution 18, 448-455.

Grafton, R.Q., Hilborn, R., Ridgeway, L., Squires, D., Williams, M., Garcia, S., Groves, T., Joseph, J., Kelleher, K., Kompas, T., Libecap, G., Gustaf, C., Makino, M., Matthiasson, T., McLoughlin, R., Parma, A., San, G., Satia, B., Schmidt, C.-C., Tait, M., Xiu, L., 2008. Positioning fisheries in a changing world. Marine Policy 32, 630-634.

Hanna, S., 2003. The economics of co-management, In: Wilson, D.C., Nielsen, J.R., Degnbol, P. (Eds.), The Fisheries Co-Management Experience: Accomplishments, Challenges, and Prospects, 1 ed. Kluwer Academic Publisher, Dordrecht, pp. 51-60.

Hauck, M., Sowman, M., 2004. Waves of Change: Coastal and Fisheries Co-Management in South Africa. Juta Academic.

Jentoft, S., 2003. Co-management: the way forward. In: Wilson, D.C., Nielsen, J.R., Degnbol, P. (Eds.), Fisheries Co-Management Experiences. Kluwer Academic Publisher, Dordrech, pp. 1-14.

Johannes, R.E., 1981. Words of the Lagoon. University of California Press.

Johannes, R., 1998. The case for data-less marine resource management: examples from tropical nearshore finfisheries. Trends in Ecology \& Evolution 13, 243-246.

Johannes, R.E., 2002. The Renaissance of community-based marine resource management in Oceania. Annual Review of Ecology and Systematics 33, 317-340.

Kaiser, M.J., Edwards-Jones, G., 2006. The role of eco-labeling in fisheries management and conservation. Conservation Biology 20, 392-398.

Lopes, P.F.M., 2008. Extracted and farmed shrimp fisheries in Brazil: economic, environmental and social consequences of exploitation. Environment Development and Sustainability 10,639-655.

May, P.H., 2008. Environmental services payments and markets: a basis for sustainable land resource management? In: Fernandes, E. (Ed.), Sustainable Agricultural Land and Resource Management Sourcebook. The World Bank, Washington, D.C., pp. 51-55.

McCay, B.J., 1981. Optimal foragers or political actors? Ecological Analyses of a New Jersey Fishery, American Ethnologist, pp. 356-382. 
McCay, B.J., Acheson, J.M., 1987. The Question of the Commons: The Culture and Ecology of Communal Resources. University of Arizona Press, Tucson.

McClanahan, T.R., Castilla, J.C., White, A.T., Defeo, O., 2008. Healing small-scale fisheries by facilitating complex socio-ecological systems. Reviews in Fish Biology and Fisheries 19, 33-47.

McGrath, D., Cardoso, A., Almeida, O.T., Pezzuti, J., 2008. Constructing a policy and institutional framework for an ecosystem-based approach to managing the Lower Amazon floodplain. Environment Development and Sustainability 10, 677-695.

Milani, P.C.C., Fontoura, N.F., 2007. Diagnostico da pesca artesanal na Lagoa do Casamento, sistema nordeste da Laguna dos Patos: uma proposta de manejo. Biociencias 15, 82-125.

Muradian, R., Corbera, E., Pascual, U., Kosoy, N., May, P.H., 2010. Reconciling theory and practice: an alternative conceptual framework for understanding payments for environmental services. Ecological Economics 69, 1202-1208.

Nunes, D.M., Hartz, S.M., Silvano, R.A.M., 2011. Fishing strategies and niche partitioningamong coastal fishers in Southern Brazil. Human Ecology 39, 535-545.

Ostrom, E., 2005. Understanding Institutional Diversity. Princeton University Press.

Pascual, U., Muradian, R., Rodríguez, L.C., Duraiappah, A., 2010. Exploring the links between equity and efficiency in payments for environmental services: a conceptual approach. Ecological Economics 69, 1237-1244.

Pinedo, D., Soria, C., 2008. El manejo de las pesquerias em rios tropicales de Sudamérica. Mayol Ediciones S.A., Bogota.

Porras, I., 2010. Fair and Green? Social Impacts of Payments for Environmental Services in Costa Rica. International Institute for Environment and Development, London.

Ring, I., Schroter-Schlak, C., 2011. Instrument Mixes for Biodiversity Policies. Helmholz Institute, Leipzig, Germany.

Ruddle, K., 2000. Systems of knowledge:dialogues, relationships and process. Environment Development and Sustainability 2, 277-304.
Ruddle, K., Hickey, F.R., 2008. Accounting for the mismanagement of tropical nearshore fisheries. Environment Development and Sustainability 10, 565-589.

Scharer, R., Ribeiro, X.R., Nascimento, J.R., 2011. Resultados economicos da pesca da lagosta Com cangalhas na prainha do Canto Verde em 2010. Mimeo, unpublished.

Seixas, C., Begossi, A., 1998. Do fishers have territories ? The use of fishing grounds at Aventureiro (Ilha Grande, Brazil). Seventh Common Property Conference, Vancouver, Canada.

Seixas, C, Minte-Vera, C Ferreira, R.G Moura, R. Curado, IB, Pezzuti, J, The, A.P.G Francini-Filho, R.B., 2009. Co-managing commons: advancing aquatic resources management in Brazil. In: Lopes, P.F.M., Begossi, A. (Eds.), Current Trends in Human Ecology. Cambridge Scholars Publishing, New Castle upon Tyne, pp. 183-204.

Souza, K.M., Silva, N.J.R., Lopes, R.G., Arfelli, C.A., 2009. Análise da política pública do defeso do camrão-sete-barbas (Xiphopenaeus kroyeri) na comunidade pesqueira do Perequê (Guarujá, São Paulo, Brazil). Leopoldianum 97, 61-71.

Teixeira, G.S., Abdallah, P.R., 2011. Politica de seguro-desemprego e pesca artesanal no Brasil: em análise o Estado do Rio Grande do Sul e a região da Lagoa dos Patos. V Meeting of Ecological Economics, Brasilia, Brazil.

Vasconcellos, M., Diegues, A.C.S., Sales, R.R., 2007. Relatório Integrado: Diagnóstico da pesca artesanal no Brasil como subsídio para o fortalecimento institucional da Secretaria Especial de Aquicultura e Pesca. SEAP, Brasilia.

Vinha, V., May, P., Begossi, A., 2010. Payments to avoid overfishing: PES potential for the Arraial do Cabo Resex in Brazil. International Conference of the Society for Ecological Economics, Oldenburg, Germany.

Wunder, S., Engel, S., Pagiola, S., 2008. Taking stock: a comparative analysis of payments for environmental services programs in developed and developing countries. Ecological Economics 65, 834-852. 